\title{
Mapping the Metaphor of the Good Neighbor: Geography, Globalism, and Pan-Americanism during the 1940s
}

\author{
Amy Spellacy
}

We have learned that our ocean-girt hemisphere is not immune from severe attack - that we cannot measure our safety in terms of miles on any map any more.

Franklin D. Roosevelt, Dec. 9, 1941

During his fireside chats, President Franklin D. Roosevelt encouraged Americans listening to their radios at home to consult their globes and follow along as he talked them through the geography of the war using the custommade globe in his study. With these geography lessons, Roosevelt hoped to bolster support for a war that was forcing people in the United States to reimagine their relationship to the rest of the world. For many Americans, the global scope of World War II reinforced their sense that the world was becoming a smaller place, a revised worldview that had emerged, in part, as a response to technological innovations, including improved radio communication and developments in air travel that dramatically reduced travel time between the United States and international destinations.

The Good Neighbor policy, which structured U.S.-Latin American relations between 1928-1947, was based on a cosmopolitan rhetoric of inter-American friendship and cooperation that relied on the central trope of the good neighbor. This essay analyzes how the metaphor of the good neighbor functioned 
discursively during the 1940s, focusing in particular on how it emerged out of and participated in shaping a new vision of the world as an interconnected whole, a shrinking space in which people developed a sense of involvement in an international community that transcended the borders of individual nations. I argue that, on the one hand, the metaphor of the good neighbor relied on and promoted a normative notion of neighborhood, drawing its meaning from images and ideals associated with literal U.S. neighborhoods. On the other hand, the metaphor was an essentially flexible, historically contingent metaphor that was adapted by Presidents Herbert Hoover and Roosevelt to meet different needs. During the period of the Good Neighbor policy, the metaphor operated through this paradoxical combination of inflexibility and flexibility to both promote a sense of inter-American community and facilitate continued U.S. economic and political domination of the hemisphere.

I begin this essay by considering the creation of the hemispheric neighborhood as a strategic spatial project, followed by a discussion of changing notions of space during World War II and Roosevelt's allegiance to the concept of the hemisphere at a time when it was being challenged by geographers and cartographers. In order to illustrate the reciprocal relationship between the architects of the policy and non-state actors, I examine how the metaphor of the good neighbor was strategically deployed in state-sponsored rhetoric at particular historical moments as well as how the hemispheric neighborhood was reproduced and reinforced by cultural texts and the people who consumed them. While the social construction of scale is often understood as a process driven by the state, geographer Sallie Marston emphasizes that "social reproduction and consumption also play a theoretically central role in the social construction of scale." In this essay, I emphasize the ways that the vision of the hemispheric neighborhood promoted by the political speeches and writings of Hoover and Roosevelt was projected in popular cultural texts that circulated in the United States during this period, enabling virtual travel to Latin America while participating in the strategic U.S. mapping of the region. ${ }^{2}$ To this end, I offer readings of several maps from works of U.S. travel literature written to promote the Good Neighbor policy as well as the 1945 Walt Disney animated feature film The Three Caballeros, arguing that the discursive strategies employed by these texts reflect U.S. imperial motives in Latin America during this period. I conclude with a discussion of the symbolic legacy of the rhetoric of the good neighbor at the 1964-65 New York World's Fair.

\section{Creating the Hemispheric Neighborhood}

The Good Neighbor policy was a U.S. plan designed to gain the respect and trust of the people and leaders of Latin America, many of whom had become distrustful of their domineering, interventionist northern neighbor during the decades of "Big Stick" diplomacy, when the United States sought to manage hemispheric politics with military occupations of countries including Nicaragua, 
Haiti, and the Dominican Republic. While the foreign policies of Hoover and Roosevelt were not identical, Roosevelt's more fully developed Good Neighbor policy can be seen as a continuation of the changes put into motion by his predecessor. Both presidents were concerned with moving away from an overtly interventionist model of U.S.-Latin American relations, improving the perception of the United States among Latin Americans, and forging greater economic and political ties within the hemisphere. ${ }^{3}$

As a spatially-based metaphor, the good neighbor drew its meaning from the geographical scale of the neighborhood. The stability of the metaphor stems from its dependence on a culturally specific, normative understanding of neighborhood. When U.S. politicians evoked the good neighbor, they did so with the expectation that their audiences would visualize a space small enough to be marked by interdependence and community, in particular a small-town residential neighborhood of single-family homes, populated by middle-class, white, Christian families. This image was deployed with the goal of creating a sense of imagined consensus between disparate and geographically distant groups, both within the United States and throughout the hemisphere.

Although the metaphor of the good neighbor consistently relied on these images of neighborhood, Hoover and Roosevelt mobilized it at particular historical moments as a flexible metaphor adaptable to specific political circumstances. In particular, the metaphor's flexibility was demonstrated by its movement from the smaller scale of the neighborhood to the larger scale of the hemisphere. The use of the good neighbor as a hemispheric political metaphor allowed the United States to promote a more expansive idea of community, using images and ideals drawn from the neighborhood to describe the hemisphere, projecting an image of a U.S. neighborhood as a homogenizing model for the hemisphere.

On the most basic level, scale is a way to distinguish between different kinds of places by recognizing the properties of particular spatial configurations, such as home, community, city, nation, and region. ${ }^{4}$ The concept of scale helps to define spaces and structure social and political relationships. Contemporary geographers, including Neil Smith and Sallie Marston, have built on Henri Lefebvre's theories of space in order to emphasize that geographical scales should be understood as social constructs rather than natural categories. ${ }^{5}$ Marston, for example, points out that "scale is not necessarily a preordained hierarchical framework for ordering the world-local, regional, national and global. It is instead a contingent outcome of the tensions that exist between structural forces and the practices of human agents." ${ }^{\prime 6}$ These insights on the nature of scales allow us to see the constructed nature of both the neighborhood and the hemisphere, and to consider how they work together in the rhetoric of the Good Neighbor policy.

By designating the space of the hemisphere as a neighborhood, the United States engaged in a process of strategic rescaling designed to accomplish the 
political and economic goals of the Good Neighbor policy. Neil Smith suggests that scale is "an active progenitor of specific social processes" and argues that "scale both contains social activity and at the same time provides an already portioned geography within which social activity takes place." Smith describes "jumping scales" as a subversive political strategy that aims to "dissolve spatial boundaries that are largely imposed from above." While Smith has pointed to the resistant possibilities in moving from a smaller scale to a wider geographical field, the process of rescaling initiated by the United States with the creation of a hemispheric neighborhood moved in the opposite direction. By describing the larger space of the hemisphere with a metaphor drawn from the smaller scale of the neighborhood, the United States effectively sought to shrink the hemisphere, creating a manageable, contained space out of what would otherwise be an unwieldy collection of geographically distant and culturally distinct nations. With this move, the United States attempted to solidify its position of power and authority over the region. The rescaling of the hemispheric neighborhood can be understood in relation to Neil Brenner's concept of "spatial tactics." Brenner, whose work focuses on critical urban and regional studies, sociospatial theory, and state theory, has described "spatial tactics" as "techniques used by the state to regulate, produce and reproduce configurations of social space adequate to the continued accumulation of capital." While the Good Neighbor policy was designed to accomplish overlapping political, economic, and ideological goals and was not focused exclusively on the accumulation of capital, Brenner's emphasis on the strategic structuring of social space on the part of the state provides a useful framework for understanding the rescaling of the hemisphere as a neighborhood.

Within the rhetorical framework of the Good Neighbor policy, the idea of the hemispheric neighborhood was particularly useful in promoting a sense of community and homogeneity in the Americas. I would suggest that the scale of neighborhood can be understood as a parallel to or a subset of the scale of community and that the properties associated with community also form the basis of the metaphor of the good neighbor. Neil Smith comments that community is "the least specifically defined of spatial scales" and points out that "the consequent vague yet generally affirmative nurturing meaning attached to 'community' makes it one of the most ideologically appropriated metaphors in contemporary public discourse." ${ }^{\prime 10}$ However, while the scale of neighborhood shares many of the ideals associated with the scale of community, neighborhood operates as both a social and a geographical category and is therefore more attached to specific places than the concept of community, which is less geographically grounded. By applying the ideals associated with community to the limited geographical space of the hemisphere, the metaphor of the good neighbor persuasively promoted a sense of inter-American affinity by appealing to the idea that neighbors are ethically responsible to look after one another and to work toward creating a more harmonious, egalitarian society in a mutually 
agreed upon bounded territory. The metaphor served to create imagined ties of obligation between individuals who were unacquainted and were unlikely to ever meet in person.

In addition to drawing meaning from the scale of the neighborhood, the rhetoric of the Good Neighbor policy also sought to reinforce the scale of the hemisphere as a meaningful category. One of the most significant features of the Pan-American, hemispheric neighborhood designed by the United States was that it was a bounded, closed space. In Seeing Like a State, James C. Scott examines how and why states have pursued large-scale improvement schemes during the twentieth century. In his analysis of how the state secures control over a space, Scott argues that "the more static, standardized, and uniform a population or social space is, the more legible it is, and the more amenable it is to techniques of state officials" and observes that "many state activities aim at transforming the population, space, and nature under their jurisdiction into the closed systems that offer no surprises and that can best be observed and controlled." 11 By transforming the hemisphere into a closed system with the rhetoric of the Good Neighbor policy, the United States created a space over which it could exert symbolic and physical control. The sense that the hemisphere should be closed off and protected was particularly pronounced following the attack on Pearl Harbor, which challenged assumptions about the safety of the geographical position of the United States. In his radio address to the nation declaring war on Japan, delivered December 9, 1941, Roosevelt suggested that the attack on Pearl Harbor illustrated the penetrability of the hemisphere: "We have learned that our ocean-girt hemisphere is not immune from severe attackthat we cannot measure our safety in terms of miles on any map any more."12 This new sense of vulnerability made the United States more eager to maintain control over the hemisphere, which was imagined as a buffer zone between the United States and Axis powers.

The specific spatial strategy of rescaling the hemisphere as a neighborhood was a kind of re-mapping that ultimately facilitated U.S. imperialism inside and outside the United States. Maps, on a basic level, are designed to create order, or the appearance of order, in accordance with the goals and priorities of the mapmaker. Maps both reflect and shape perceptions of space and social relationships by offering a simplified, abstracted, and necessarily biased representation of a particular place. While Scott concedes that the ordering work done by the state, including mapping, is necessary to create a functional society, he emphasizes that maps ultimately facilitate state control. ${ }^{13}$ In his work on the discursive nature of maps, cartographic historian J.B. Harley examines how visual representations of power are embedded in maps and suggests that maps are used to create structures of social relations that support the status quo. He argues that cartography is a form of knowledge and power, that maps are a language, and that the iconology of maps reveals a deeper level of meaning. ${ }^{14}$ Harley is among those scholars who remind us that despite the seductive, 
apparently scientific representation of space provided by maps, they are not straightforward reflections of the physical world:

Maps cease to be understood primarily as inert records of morphological landscapes or passive reflections of the world of objects, but are regarded as refracted images contributing to dialogue in a socially constructed world. . . . Both in the selectivity of their content and in their signs and styles of representation maps are a way of conceiving, articulating, and structuring the human world which is biased towards, promoted by, and exerts influence upon particular sets of social relations. By accepting such premises it becomes easier to see how appropriate they are to manipulation by the powerful in society. ${ }^{15}$

By enabling both the rhetorical and physical mapping of the Americas, the metaphor of the good neighbor facilitated continued U.S. domination of the hemisphere. Through the creation of the construct of the Pan-American neighborhood, the United States participated in a process of imperial mapping that conveniently justified U.S. appropriation of Latin American resources during World War II. Because we are neighbors, the United States argued, we have a right to your political allegiance and your natural resources.

\section{Re-imagining the Hemispheric Neighborhood After Pearl Harbor}

In a 1941 essay in The Saturday Review of Literature, Alexander Cowie argues for the importance of studying foreign languages "in a world so shrunken geographically that nations once regarded as remote now become virtual neighbors." ${ }^{16}$ Cowie's use of the phrase "virtual neighbors" to describe residents of foreign countries indicates the extent to which an expanded understanding of the category of the neighbor had emerged by the early 1940s. With his announcement of the Good Neighbor policy in 1933 and his promotion of the good neighbor ideal through the Good Neighbor League during the 1930s, Roosevelt had propitiously laid the ground work for a war-time policy that attempted to dislodge the U.S. tendency toward isolationism and encourage U.S. residents to imagine themselves as neighbors to foreigners in far-flung places of the globe. ${ }^{17}$ Conveniently, the political need to transform Latin Americans into neighbors coincided with developments in mapping and geography that emphasized the interconnected nature of the world and favored the use of globes, rather than maps, to represent the earth. While these developments supported Roosevelt's Good Neighbor policy and his general view of the world as an interconnected system, this new view of the world also deemphasized the scale of the hemisphere, a crucial geographical concept for the 
Good Neighbor policy. In his war-time speeches and writings relating to the Good Neighbor policy, Roosevelt incorporates the elements of this new geography that support his cause, while ignoring those that do not.

With the Japanese attack on Pearl Harbor on December 7, 1941, it became eminently clear to the United States that it was not out of the range of the reach of its enemies. This catastrophic event illustrated that the world needed to be imagined as an interconnected system. If the attack on the Hawaiian islands forced Americans to rethink the presumed geographical divide between East and West, the declarations of war by Germany and Italy would add to the sense that the world was closing in on the United States. ${ }^{18}$

When the United States entered the war, Roosevelt believed that people needed to be taught about world geography in order to understand U.S. military strategy and the global scope of the war. He reasoned that an understanding of geography would be essential in gaining the approval to send large numbers of American troops to fight in remote locations around the world and dedicated several of his fireside chats to educating the public about the geography of the war. ${ }^{19}$ In a radio address delivered on February 23, 1942, Roosevelt asked Americans to take out their maps and follow along as he updated them on the status of various battles around the world. ${ }^{20} \mathrm{He}$ suggested to the American people that the global nature of the war required new strategies and a new understanding of geography:

The present great struggle has taught us increasingly that freedom of person and security of property anywhere in the world depend upon the security of the rights and obligations of liberty and justice everywhere in the world. This war is a new kind of war. It is different from all other wars of the past, not only in its methods and weapons but also in its geography. It is warfare in terms of every continent, every island, every sea, every air-lane in the world. That is the reason why I have asked you to take out and spread before you (the) a map of the whole earth, and to follow with me in the references which I shall make to the world-encircling battle lines of this war. ${ }^{21}$

In this address, Roosevelt uses geography to encourage a sense of obligation and investment in the war, prompting Americans to see themselves as a part of a global system. He comments, "We must all understand and face the hard fact that our job now is to fight at distances which extend all the way around the globe." 22

Roosevelt himself was an enthusiast of geography and maps. In 1942, General George C. Marshall presented Roosevelt with a 50 -inch globe as a Christmas gift from the U.S. army. ${ }^{23}$ Roosevelt kept the globe by his desk in the Oval Office so that he could plan military strategy and follow troop movement 
during the war. Other wartime leaders, including Winston Churchill, were also given replicas of the huge globe, which was manufactured by the Weber Costello Company of Chicago Heights, Illinois, under the direct supervision of the Office of Strategic Services and the War Department. ${ }^{24}$ The globe was created at a scale of 1:10,000,000 (157.8 miles to the inch) and mounted on rubber rollers so that it could be rotated in any direction. In an editorial in The Geographical Review, written shortly after Roosevelt's death in 1945, Isaiah Bowman describes Roosevelt as an aficionado of geography. Bowman suggests that Roosevelt's experiences as a sailor and a navigator instilled in him a life-long interest in maps and comments that during his period of convalescence with polio Roosevelt passed the time reading old atlases. ${ }^{25}$ A 1942 photograph taken of Roosevelt with his globe both promotes the use of globes and asserts Roosevelt's control over the world he surveys (Figure 1). J.B. Harley has commented that "as a politically laden sign the globe or orb has frequently symbolized sovereignty over the world" and notes that "in newspapers, on television screens, and in innumerable political cartoons, military leaders are frequently shown in front of maps to confirm or reassure their viewers about the writ of power over the territory in the map." ${ }^{26}$ This photograph of Roosevelt at his desk leaning toward his globe assures viewers that the war, and the world, are being carefully managed under the U.S. president's watchful gaze.

For both cartographers and the American public, World War II brought about a transformation in the way that the world was understood and represented.

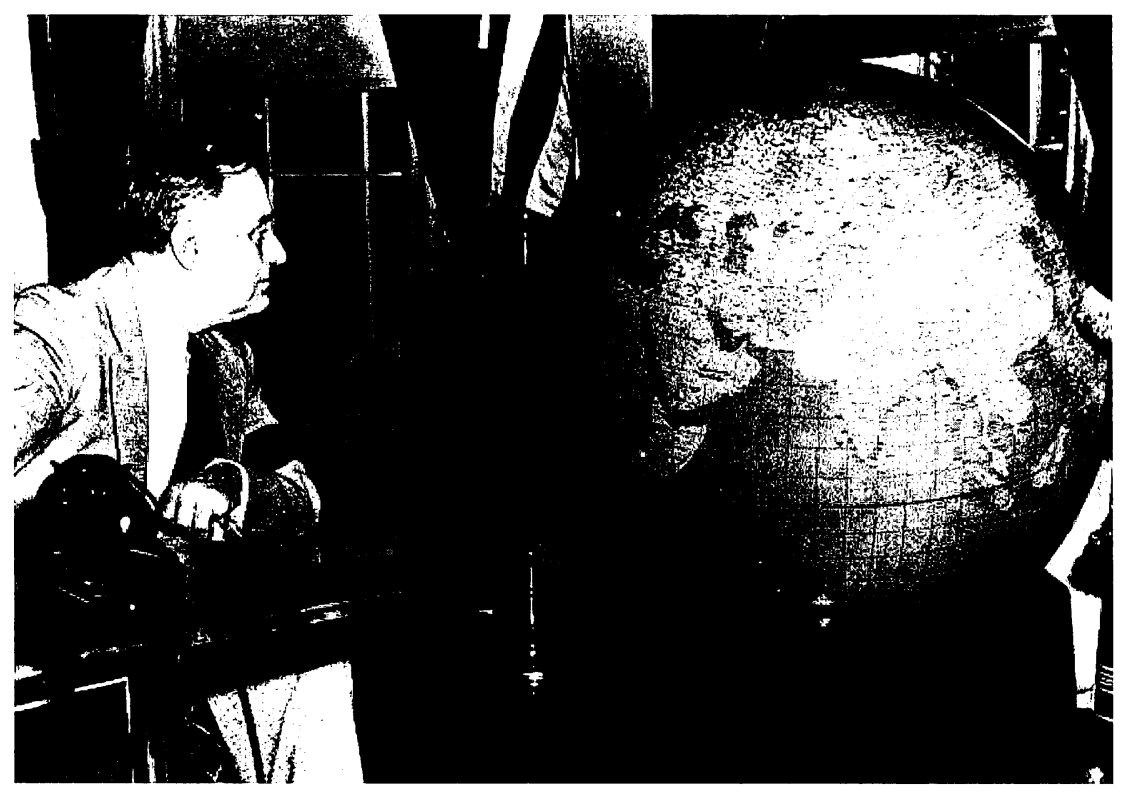

Figure 1: Franklin D. Roosevelt. 1942. Courtesy of Franklin D. Roosevelt Library, Hyde Park, New York. 
Alan K. Henrikson has argued that the geographers and cartographers of World War II shared a "definitive substantive conception of the world" that he terms "Air-Age Globalism." ${ }^{27}$ One of the central features of this conceptual shift was a new interest in the sphericity of the earth and the rejection of maps based on Mercator's projection in favor of globes, which were preferred because they presented a less distorted, more accurate representation of the earth. ${ }^{28}$ This change in geographical psychology was also characterized by a new realization of the earth's continuity and unity that resulted from seeing and imagining the earth from an aerial perspective. Finally, the Air-Age Globalists shared a cartographic fixation on the arctic, which emphasized the geographical proximity of the Soviet Union to the United States, a factor that Henrikson links to the development of the Cold War in the period following World War II.

The turn toward Air-Age Globalism among professional geographers and cartographers also impacted the ways that the American public perceived and represented the world. The war generated widespread popular interest in geography, which was fed by the map supplements printed by many newspapers and magazines, including Fortune, Life, and National Geographic. ${ }^{29}$ Additionally, the move from the map to the globe translated into popular interest in acquiring and using globes: "In order to avoid the strategic fallacies of the 'Mercator mind,'Americans were sometimes advised to give up looking at deceitful maps altogether and instead to contemplate their household globes, using pieces of string rather than rulers for measurement and direction finding. ${ }^{130}$ Commercial map firms built cheap globes to meet public demand for this popular representation of the world. In a 1943 article, "The War of the Maps," geographer Richard Edes Harrison provides an overview of maps and globes for an American public eager to track the events of the war. Harrison advocates the use of a globe and suggests that many of the globes made by commercial map companies have "eliminated the fixed axis in favor of a universal free movement base," an innovation allowing the globe to be repositioned from different angles, like Roosevelt's famous globe. ${ }^{31}$ A 1943 advertisement in The Saturday Review of Literature promoted the eight-inch "Liberty" globe from the Denoyer-Geppert Company as a "World Without an Axis" (Figure 2).

As a reflection of this new-found public interest in geography and globes, images of globes and spheres meant to evoke the globe began to appear in cultural texts, including advertising and corporate logos. During the 1940s, Coca-Cola's print advertisements in U.S. magazines featured the red circle logo, which was imprinted with an outline of the continents. The Pan-American Airways Terminal in Miami showcased a huge globe in the lobby of the terminal, measuring 311/2 feet in circumference and weighing 6,000 pounds.

While proponents of Air-Age Globalism subscribed to a view of the world as an interconnected system that complemented the worldview promoted by the U.S. Good Neighbor policy, the Air-Age Globalists also rejected the division of the world into separate hemispheres, one of the foundational concepts used to 


\section{WORLD WITHOUT AN AXIS New "Liberty" Mounting g GLOBE}

At wrod globe in a rety unatble sty le of mustring.

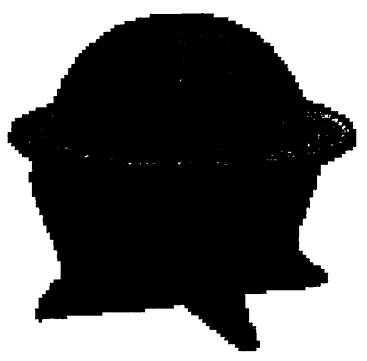

8" Cradle Mtg. "Liberty" Globe Axis Free

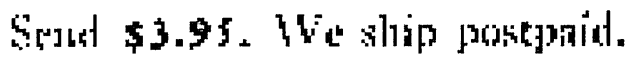

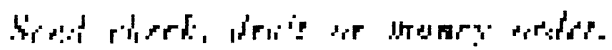

DENOYER.GEPPERT CONFAMY

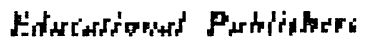

5241 Ravenswat Awe., Chlemet 40

Figure 2: Advertisement for Denoyer-Geppert Company. The Saturday Review of Literature, August 7, 1943, 26.

structure U.S.-Latin American policy during this period. Air-Age Globalists regarded the notion of the hemisphere as "a willfully generated, self-deceiving, unscientific "myth." "32 Arthur Whitaker notes that the idea of the Western Hemisphere, which was the space designated as off limits to European powers with the 1823 Monroe Doctrine, originated in part with European maps that divided the world into two halves, one centered on Europe, the other on the New World.$^{33}$ In Hemispheric Imaginings: The Monroe Doctrine and Narratives of U.S. Empire, Gretchen Murphy highlights the connections between the concept of the Western Hemisphere and U.S. foreign policy, focusing in particular on how the Monroe Doctrine was dependent on and contributed to the geographic construction of the hemisphere..$^{34}$ The Western Hemisphere has conventionally been defined as "the mathematical half section of the globe extending between $20^{\circ} \mathrm{W}$. and $160^{\circ} \mathrm{E}$. of Greenwich," including South America, Central America, the United States, Canada, and parts of Iceland and Greenland. ${ }^{35}$ A 1940 article 
in The Geographical Review provides a map of the boundaries of the Western Hemisphere, noting that the Western Hemisphere is "admittedly a shade smaller than the Eastern Hemisphere" (Figure 3). ${ }^{36}$

Prior to Pearl Harbor, the United States had drawn the boundaries of the Western Hemisphere in order to "define a practically defensible security zone and to increase the political solidarity of North and South America." ${ }^{\prime 37}$ The attack on Pearl Harbor, of course, pointed out the arbitrariness of this supposedly defensible zone. The new focus on the use of globes, rather than maps, also made clear to many that the hemisphere was an artificial geographical construct that grouped together places that were, in reality, more distant than many nonhemispheric locations.

While the attack on Pearl Harbor required people to rethink the relationship between the United States and the rest of the world, the idea that the Western

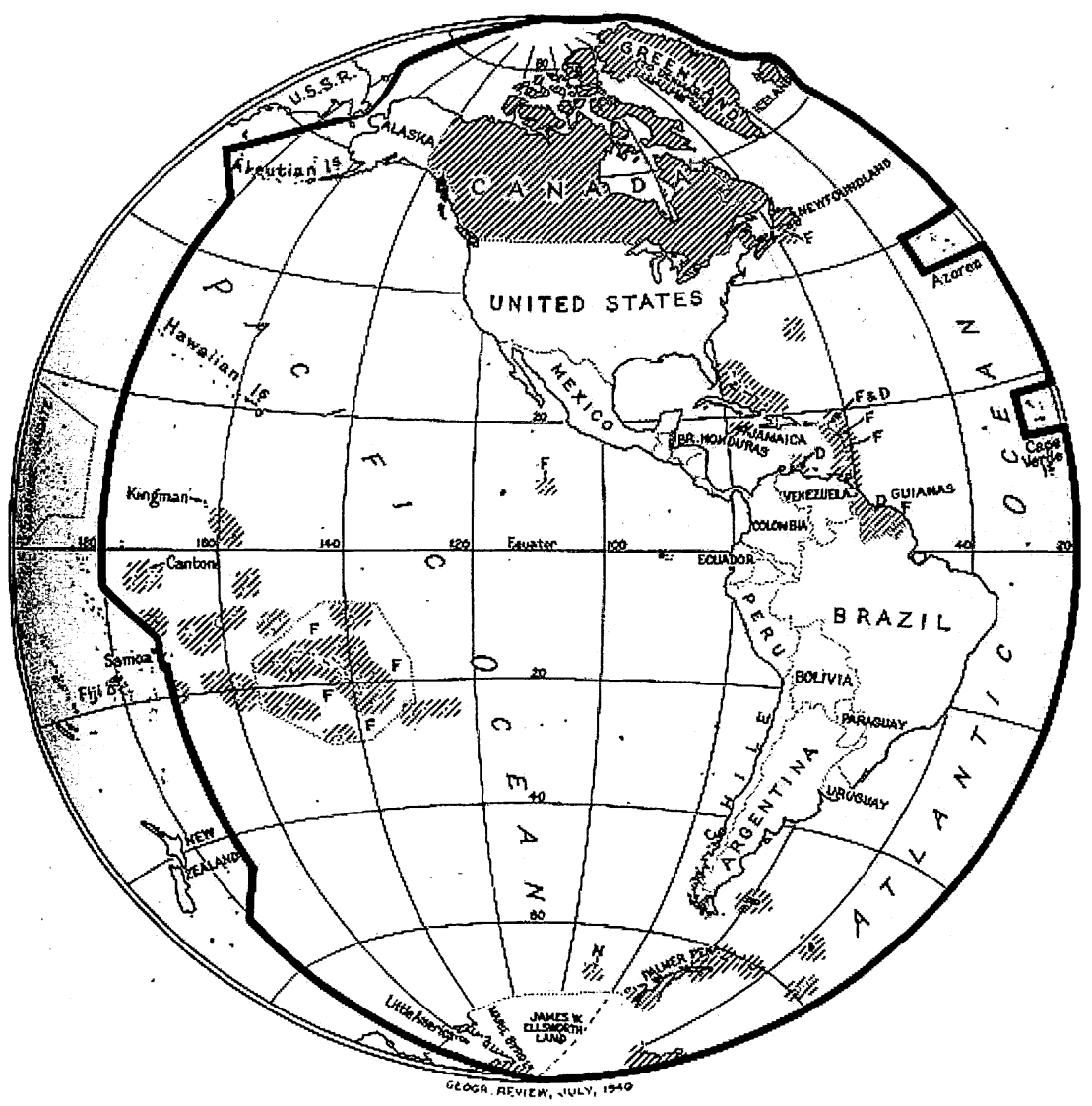

Figure 3: The Western Hemisphere. The Geographical Review 30 (1940), 527. 


\section{Amy Spellacy}

Hemisphere was the most natural strategic alliance for the United States had been challenged before the momentous attack drew the United States into the war. In an article in Foreign Affairs in April 1941, Eugene Staley discredited the notion of self-contained economic regions by proposing that readers consult a globe and "attach a string to a pin at Madison, Wisconsin," home of Wisconsin Governor Philip La Follette, a hemispheric isolationist, and rotate the string to measure distances between Madison and points around the world. ${ }^{38}$ With this exercise, readers were to discover that many locations in the Western Hemisphere were actually much farther away from Madison than locations in other parts of the world. Staley notes that "no capital in Europe, including Moscow, is as far from Madison as is Buenos Aires, and only one European capital (Athens) is as far as Rio de Janeiro." ${ }^{39}$ He also comments that "Gibraltar is closer to Madison than is the capital of Bolivia, closer than Tacna or Arica, and closer than any major city in Brazil or any place at all in Argentina, Chile, Paraguay, or Uruguay." 40 Staley discredits the idea that continental or land connections are the most significant factors to take into account when forming economic or political alliances, emphasizing instead the ways that oceans function to facilitate communication and trade. ${ }^{41}$

For Staley and others who supported a reorientation of U.S. foreign policy toward Europe, the idea of the Western Hemisphere was seen as an outdated model for understanding the place of the United States in the world. Staley discredits the notion of continental unity ultimately to support a stronger alliance between the United States and Britain:

The United States should regard Western Hemisphere defense lines as distinctly secondary, to be prepared for emergency use if the first line breaks and we are forced to fall back for a last-ditch stand. It is less-risky to stand now for all-out defense, together with Britain, of the seas and the strong-points commanding the seas of the whole world-Singapore, Hawaii, Panama, Gibraltar, Suez, and Britain itself - than to let Britain go down and then to try to defend the Western Hemisphere practically alone. ${ }^{42}$

Staley's view that an alliance with Britain should be prioritized over interAmerican solidarity was echoed by Francis Pickens Miller in a July 1941 article in Foreign Affairs. ${ }^{43}$ Miller emphasizes the strategic importance of the "Atlantic Area" and suggests that the Western Hemisphere is no longer the defining area for American foreign policy. He positions the Atlantic Area as "the cradle of our civilization," and connects the defense of this zone with the "survival of the American way of life." 44

While Roosevelt adopted many of the central ideas of Air-Age Globalism, he clung to the notion of the Western Hemisphere although the concept of hemispheres was being challenged by geographers and scholars of foreign policy 
and despite his military, economic, and political commitment to Britain. Roosevelt's continued allegiance to the idea of the hemisphere can be directly tied to the wartime economic and political motives of the Good Neighbor policy. After the United States entered the war, the broad goals of the pre-war policy were refocused around particular needs, especially the need to secure the natural resources of Latin America. While the United States continued to pursue the goals of countering Axis propaganda on the cultural front and courting Latin American leaders as political allies, the economic needs of war-time production in the United States added a new element of urgency to the policy. The United States needed that cup of sugar from its neighbors in the Caribbean, as well as tin from the mines of Bolivia and rubber from the Amazon region to build airplanes and tanks for the war overseas. By continuing to promote a rhetoric of hemispheric solidarity, the United States was able to lay claim to the resources of Latin America as part of the larger Pan-American war-time effort. Without the notion of the hemisphere, it would have been much more difficult for the United States to articulate the relationship of inter-dependence that it sought to promote. Roosevelt's continued use of the concept of the hemisphere was one way that the United States used strategic mapping to exert control over the region.

\section{Travel and Virtual Travel in a Shrinking World}

Roosevelt's expanded use of the category of neighbor on a hemispheric scale was facilitated by improvements in transportation technology and infrastructure that encouraged contact and exchange between the United States and Latin America, making the concept of the Latin American neighbor more viable. A 1935 article promoting travel to Latin America in The Literary Digest highlights the increased accessibility of Latin America for American travelers: "Mexico and other 'foreign lands a step away' in Central America become more accessible each year, and passage to the East and West Coasts of South America is facilitated by more frequent sailings." ${ }^{\text {45 }}$

A perceptual shift marked by the idea that the world was becoming a smaller place had begun to emerge during the 1920s and 1930s, due largely to improvements in transportation technology that brought people into contact with one another in new ways. In a letter dated September 12, 1936, Roosevelt acknowledges this new understanding of the world, using the metaphor of the hemispheric neighborhood to describe an emerging community of people in the Americas: "Buenos Aires, Santiago, Rio de Janeiro are now nearer to Montreal and Chicago than Boston was to Philadelphia when the Constitution of the United States was framed," Roosevelt wrote. "Only since yesterday, it seems the Hemisphere has become a vast neighborhood." ${ }^{46}$ The new accessibility of remote locations through airplane travel contributed to the general sense that the world was more accessible, and therefore experienced as a smaller space.

The global scope of U.S. involvement in the war accelerated this perceptual shift, which rejected isolationism in favor of a recognition of new international 
networks and associations. In a 1944 article in The Journal of Geography, "What the War Has Taught Us About Geography," George T. Renner suggests that

Technological advances have shrunk and remoulded the world to where the physical basis of isolation no longer exists. The airplane and the radio have brought the peoples of the entire world into a close community which is now smaller in accessrelationships than was the United States twenty-five years ago. The airplane and the radio have produced a new planetary human ecology. ... Masses of unlike peoples are beginning to rub elbows so sharply, that either perpetual warfare or a cooperative world order must result. ${ }^{47}$

Renner suggests that people felt as if the globe were being reshaped and resized by new technologies, resulting in a new sense of global community.

The promoters of the Good Neighbor policy had long understood that the policy would be strengthened by increased access between the United States and Latin America. Thus they made efforts to improve automobile travel through the Pan American Highway and air travel through Pan American Airways. During the Good Neighbor policy, the ability to travel between the United States and Latin America was significantly bolstered by the construction of the Pan American Highway and the development of an improved network of airplane travel within the hemisphere, dominated by Pan American Airways. ${ }^{48}$ While the Pan American Highway was first conceived of at the Fifth Pan-American Conference in Santiago, Chile, in 1923, before the beginning of the Good Neighbor policy, construction of the highway continued throughout the period of the policy. ${ }^{49}$ Historian George Black suggests that the U.S. auto industry "latched on quickly" to the idea of the highway, undoubtedly because it provided a new destination for Americans in their cars and also opened up new markets of car-buyers in Latin America. ${ }^{50}$

Pan American Airways, which was subsidized and supported by the U.S. government, benefited from U.S. commercial and strategic interest in Latin America by becoming "the government's unofficial 'chosen instrument' for overseas aviation operations." ${ }^{.51}$ In 1927, the U.S. government initiated this important relationship with Pan American by awarding the airline the Post Office mail contract from Key West, Florida, to Havana, Cuba, a route that was later expanded to include other parts of Latin America. Pan American was also involved with U.S. operations during World War II and after the war enjoyed a boom in prosperity because of increased American tourism and international business travel.

During the 1940s, advertisements for transportation and tourism promoted travel to South America as a good-neighbor activity. In these ads, South America is showcased as a glamorous destination where wealthy Americans can experience romantic sights and historic cities. A Pan-American Grace Airways ad from 
November 1940 appeals to Americans by highlighting the fact that "It's Springtime in Chile, South America" (Figure 4). The ad features sophisticated people in eveningwear and promotes the "Panagra Route," a tour of the major sights in South America. An ad for Moore-McCormack Lines enticed American travelers to Latin America with the "luxury of a superb cruise liner" and the "glamour of South America" on the "Good Neighbor Fleet." The ad explained that the ships sailed from New York and stopped in "ports excitingly beautiful" throughout South America. ${ }^{52}$

Both because of the push to imagine Latin Americans as neighbors and because of the improved travel infrastructure, the 1940s also saw a boom in travel literature written about Latin America by U.S. authors. In books such as Constance Matilda Jordan Henley's Grandmother Drives South (1943), Milton Reynolds' Hasta La Vista (I'll Be Seeing You) (1944), and Herbert Cerwin's These Are the Mexicans (1947), the people and places of Latin America were brought to life with colorful anecdotes and sweeping generalizations about national character and cultural traditions. ${ }^{53}$ One of the conventions of these travel books was to include maps on the inside front and back covers of the book in order to provide readers with a visual representation of the places described in the text. The imperial economic motives of the wartime Good Neighbor policy were particularly evident in these maps, which reflect the U.S. interest in securing the resources of Latin America for the war effort. These maps can be read as offering a version of an interconnected world community that benefits the United States, suggesting that because the United States and Latin America are neighbors, the United States has a right to the resources of the region. Rather than using the geographical innovations of the day to re-imagine a more egalitarian, truly neighborly relationship, both Roosevelt and U.S. travel writers continued to stake a claim on the land and resources of Latin America.

With little regard for the people and places of Latin America, these maps present the region as a storehouse of natural resources and a projection of imperialist fantasies. A map used to illustrate Carleton Beals' 1940 book Pan America: A Program for the Western Hemisphere labeled each country in Central America, South America, and the Caribbean in terms of the resources that come from that country. ${ }^{54}$ The map, entitled "The South American Storehouse," also included a list of "potential products" for each country, highlighting the extent to which the United States saw the region as a territory that could be developed according to its needs. Guatemala, for example, provided the hemisphere with coffee, bananas, hides, sugar, and cotton, but also had the potential, according to Beals, to produce coconuts, rubber, antimony, zinc, iron, and lead. Small line drawings of products on particular countries add to the effect of defining the region in terms of the resources it had to offer the United States. Argentina is illustrated with the head of a steer, and Brazil is indicated with bags of coffee and diamonds.

The map used to illustrate John L. Strohm's 1943 book I Lived with Latin Americans follows the tendency of Beals' book to map the hemisphere in terms 


\section{Its Springtime in CHILE, SOUTH AMERICA}

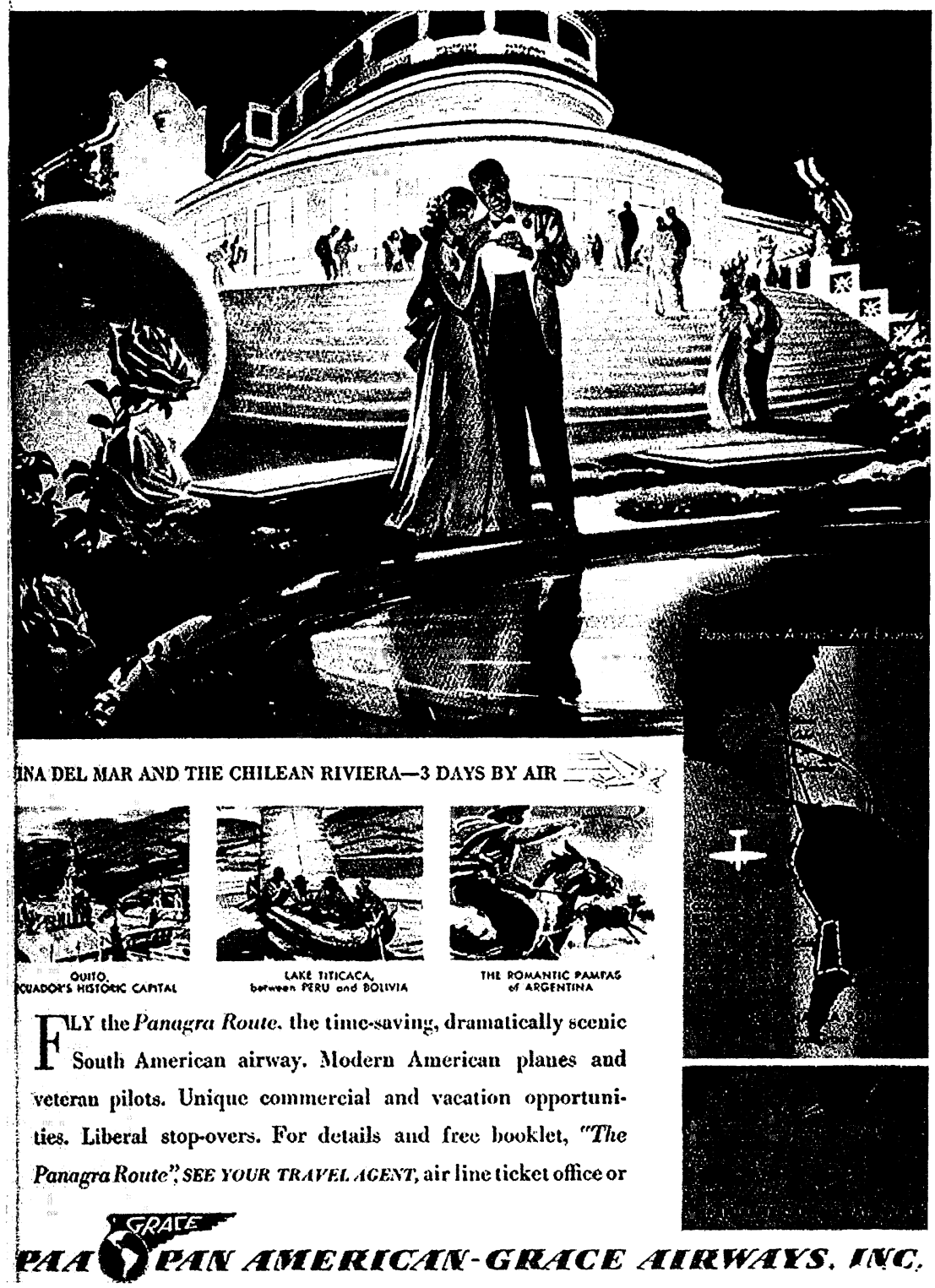

Figure 4: Pan-American Grace Airways. National Geographic, November 1940. 
of resources, but goes even further in promoting an imperialist vision of the region by removing all significant geopolitical markers, such as national boundaries, and by using cartoon images to illustrate the map, making Latin America seem childlike and simple (Figure 5). ${ }^{55}$ The cartoonish quality of the images and the hand-drawn effect suggests that even an amateur can map this territory and reinforces the control over the space exhibited by the North American author of the text. Images of rubber tires, tin cans, sugar cubes, and banana trees dot the colorful map. The map promotes a colonial vision of the region by suggesting that resources are unusually abundant and of incomparable quality, such as the "Grapes as big as lemons" that the map locates in Chile.

In addition to making Latin America seem childish and offering up the resources of the region for U.S. consumption, this map also includes images that remind viewers of the long history of colonialism in the Americas, promoting the idea that Latin America has historically been and continues to be controlled by outside powers. Mexico features a matador and a charging bull, a reminder of the Spanish legacy. Cuba is illustrated by a white man puffing on a giant cigar and a black man holding a bag of sugar, indications of the persistent racial divisions in Cuban society. A black woman balancing a tray of fruit on her head stands on the island of Hispaniola, designating that this was the location of the "First Negroes in America" while making no reference to the slave trade. The history of the invasion and colonization of the region is trivialized and romanticized with the image of a ship near the island of San Salvador (or Watling's Island), in the Bahamas, labeled "Columbus' First Landing," and with the image of a pirate straddling several islands in the Caribbean, the location of "Old Pirate Lairs." A group of islands off the coast of Peru are labeled as "Guano Islands" to indicate their importance as a source of the fertilizer composed of seabird droppings, a major nineteenth-century export from South America to Europe. Juan Fernández Island, off the coast of Chile, is labeled "Robinson Crusoe's Island," in honor of the famous colonial adventure novel by Daniel Defoe which was inspired by the island. The protagonist of the novel is pictured with Friday, the native man that Crusoe saved from cannibals and then enslaved, naming him Friday to commemorate the day on which he was "rescued." There are also several tourist attractions indicated on the map, including "Maya Ruins" in the Yucatán and Iguassú Falls, located at the border of Brazil and Argentina.

The 1945 Disney film The Three Caballeros, which uses the trope of virtual travel to introduce audiences to the region, replicates the vicarious experience of learning about Latin America through travel literature. ${ }^{56}$ The Three Caballeros, a full-length Technicolor feature, was one of several films to emerge from material collected by Walt Disney and select members of his staff on three research trips to Latin America between 1941 and 1943. ${ }^{57}$ Working in cooperation with the Office of the Coordinator for Inter-American Affairs, the U.S. government office concerned with the cultural promotion of the Good Neighbor policy, Disney also produced a documentary of the group's travels, South of the Border with 


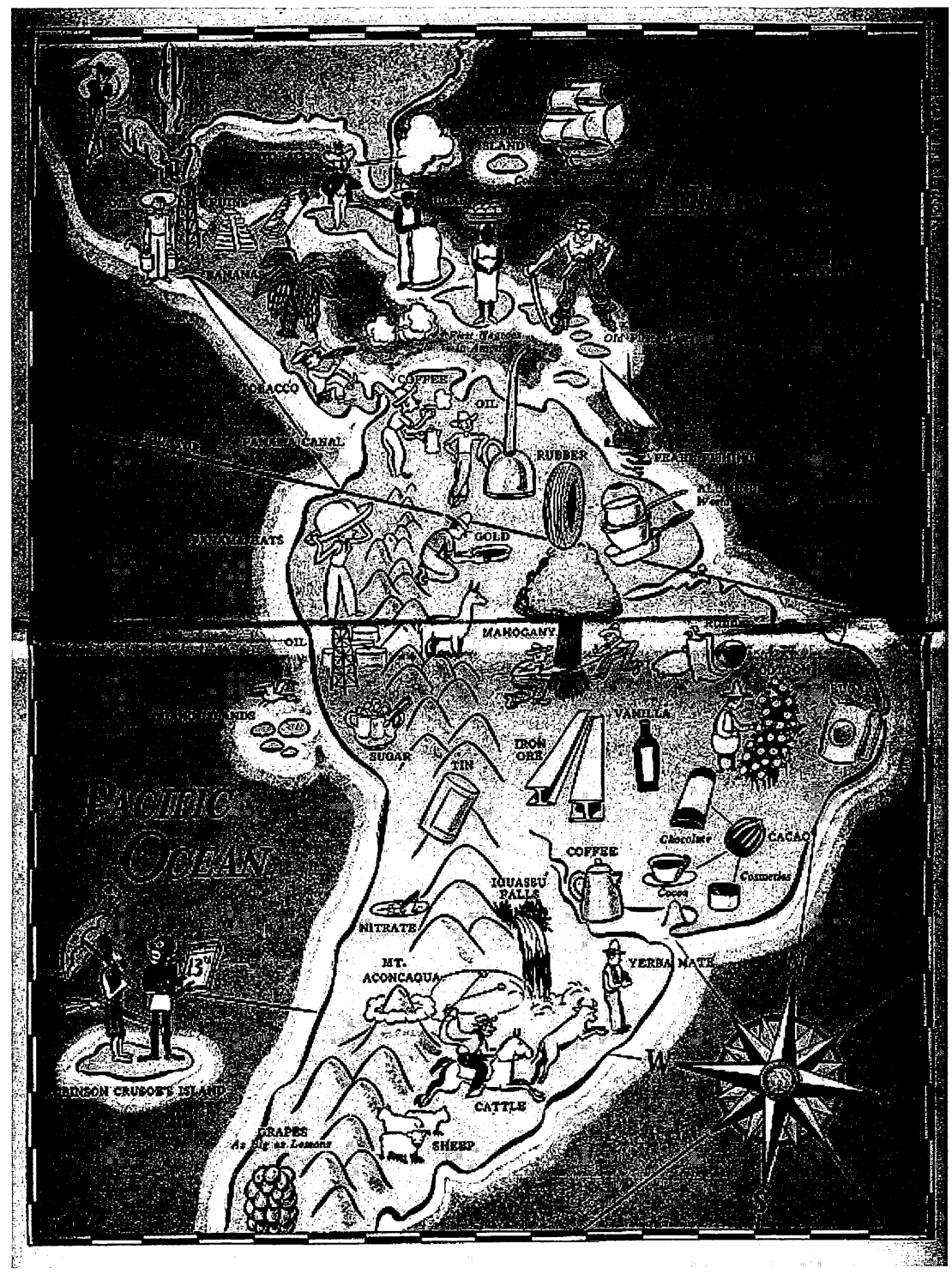

Figure 5: John L. Strohm, I Lived with Latin Americans (Danville, Ill.: The Interstate, 1943).

Disney (1941), and a film that combined documentary footage with a series of animated shorts, Saludos Amigos (1943). The Three Caballeros centers on the adventures of three central cartoon bird characters, Donald Duck, representing the United States, Panchito, a gun-toting Mexican Revolutionary rooster, and Joe Carioca, a parrot dressed as a Brazilian businessman, with an umbrella, 
bowler hat, and cigar. ${ }^{58}$ The film opens with Donald Duck receiving a surprise package from his friends in Latin America that contains three separately wrapped gifts. Each of the three "gifts" offers Donald an opportunity to learn about Latin America through virtual travel. That Donald receives these "gifts" from Latin America sets the stage for a film in which Latin America offers itself to Donald Duck and therefore to the United States.

The first package contains a projector and a film entitled Aves Raras, or Rare Birds, that teaches Donald about various species of birds in Latin America, introducing the theme of virtual travel. The second package is a book entitled Brasil. When Donald opens the book, Joe Carioca steps out and invites Donald to enter the book with him to learn more about Brazil. By framing the adventure sequences with Donald stepping in and out of the book, the film continues to emphasize the parallels between reading about Latin America, an opportunity available to American audiences watching the film, and Donald's adventures. The third package that Donald opens is a Mexican piñata that also contains a book entitled Mexico. Once again, the book serves as an indicator of the possibilities of virtual travel. The three birds enter and leave the book Mexico on a magic serape that allows them to fly high above the region and zoom in on particular places to experience Mexican culture, such as folk dancing in Veracruz. At one point, Panchito also holds up a photograph for his friends as he tells them about the Mexican Christmas tradition of las posadas. Throughout the film, books, photos, maps, and movies function as Donald's inroads to learning about Latin American culture, with Joe Carioca and Panchito serving as the tour guides on his virtual adventures. ${ }^{59}$ The film blurs virtual travel and actual travel by having the books come alive with three-dimensional, pop-up pages and live action photos and movie segments, promoting the idea that everyone can share in Donald's experiences.

Like the maps from U.S. travel books, which define Latin America in terms of resources available for U.S. consumption, The Three Caballeros maps the region in terms of U.S. desires, substituting the women of Latin America for the resources coveted and claimed in the maps. Both the maps and the film offer the fantasy of unobstructed access to the resources and women of Latin America. The original theatrical trailer for The Three Caballeros pitches the film's technological innovation in combining live action and animation, describing this aspect of the film as "the newest thing to hit the movies since talking pictures came in," and provides a preview of the three female Latin American entertainers featured in the live-action segments, Aurora Miranda, Carmen Miranda's sister; Carmen Molina, a Mexican dancer; and Dora Luz, a Mexican radio and screen star. ${ }^{60}$ The trailer also appeals to audiences by promising "a whole screen full of Latin American lovelies" in addition to the three central female stars.

In The Three Caballeros, Latin America is positioned as the object of sexual desire for Donald Duck, who is represented as an oversexed sailor whose experience of the region involves chasing women in the various countries visited 
by the three "caballeros." ${ }^{\text {"1 }}$ On the one hand, Donald Duck's status as a cartoon character who imitates stereotypical sailor behavior makes his predatory pursuit of real women less threatening. However, if Donald is viewed as a stand-in for the Disney corporation or for actual U.S. military personnel, then the romantic adventures of the cartoon bird, the source of much of the humor of the film, disguise the real threat of U.S. corporate and military aggression beneath an innocent veneer. In a particularly telling scene, the three birds fly over Acapulco beach on a magic serape, admiring the Mexican women sunning themselves. Donald is so overcome with attraction that he jumps from the serape and, as he plummets toward the beach, takes the shape of a bomb targeting the women. The women in swimsuits screech and take cover as Donald dive-bombs them. In a later scene, Donald daydreams about all the women he has seen in Latin America while images of throbbing hearts fill the screen and he repeats a mantra of "pretty girls, pretty girls."

The live action segments of the film focus primarily on the romantically charged interactions between Donald and the three female entertainers from Latin America. His interest in the women is often reciprocated, suggesting that Latin American women are available and receptive to the advances of North American men. In the world represented in the film, there are no men to challenge Donald, except for the other two "caballeros," who occasionally restrain him, but generally support him in his quest for Latin beauties. Although the film was shown to audiences in the United States and Latin America, it creates a surreal world where Latin American women sing, dance, and proffer their bodies, and the fruits of their countries, for Donald and for the United States, reminding viewers of cultural and sexual hierarchies controlled by North American men. By substituting Aurora Miranda for her sister Carmen in the role of a Brazilian Bahiana, The Three Caballeros builds on the image of Carmen Miranda, perhaps the most famous feminized representation of the region from this period. With the fruits of Latin America literally piled onto her head, Miranda suggestively offered Latin America up for U.S. consumption.

The maps from U.S. travel literature and The Three Caballeros serve as evidence of the ways that cultural texts reinforced the rhetoric of the Good Neighbor policy. While they endorse the idea of the hemispheric neighborhood, they also highlight the unevenness of the supposedly reciprocal relationship promoted by the policy. By reading travel books, watching films about the region, and following the geography of the war with their globes, people in the United States mapped and claimed Latin America as a part of the inter-American neighborhood and were introduced to the idea of a broader world community.

\section{Conclusion: From the Hemisphere to the Unisphere}

Although the metaphor of the good neighbor faded into the background during the postwar period, it provided the foundation for a new rhetoric of internationalism that placed the United States at the center of the expanding 
U.S. neighborhood. The "It's a Small World" exhibit at the 1964-65 World's Fair provides a way of examining the legacy of the good neighbor, illustrating one way that the rhetoric of the Good Neighbor policy continued to resonate in U.S. culture, long after the policy had been discontinued.

While some scholars have suggested that the Good Neighbor policy ended with Roosevelt's death in 1945, others have pointed to the significance of the 1947 Truman Doctrine and the realignment of U.S. foreign policy goals toward the Marshall Plan in Europe in signaling the end of the policy. With the Truman Doctrine, the United States "assumed the right to police the globe against communist threats wherever they were detected," essentially reverting to the same principles that guided pre-Good-Neighbor-era U.S.-Latin American relations and inaugurating the logic of the Cold War. ${ }^{62}$ Historians of the early Cold War period suggest that the virulently anti-Communist rhetoric of the Truman Doctrine was employed by the administration as a way of convincing the increasingly isolationist U.S. public of the need to undertake a massive European Recovery Program, a plan that Truman felt was necessary to ease the U.S. economy through the postwar period by turning Europe into an economic partner of the United States. ${ }^{63}$

Writing in 1954, Arthur Whitaker suggested that during the immediate postwar years, the concept of the Western hemisphere lost relevance and temporarily gave way to an enthusiasm for globalism. According to Whitaker, the ideal of global community was soon replaced by Cold War divisions: "After 1940 the substance of the Western Hemisphere idea was lost, and its place was taken first and briefly by globalism and then by new twofold divisions of the globe, not into the traditional Eastern and Western hemispheres, but into Northern and Southern hemispheres, or, more frequently, into the communist and noncommunist worlds." ${ }^{\prime 64}$ In spite of the predominance of these new Cold War divisions, I suggest that the rhetoric of hemispheric community that emerged during the 1940s informed postwar ideas of international community that lingered on during the Cold War and helped place the United States at the center of the global economic and political community.

The 1964-65 World's Fair, a public event concerned with projecting an image of the relationship between the United States and the larger world community, provides evidence of the links between the rhetoric of the Good Neighbor policy and postwar internationalism. Held at Flushing Meadow, in Queens, New York, on the site of the 1939-40 World's Fair, the 1964-65 fair was centered on the theme "Man in a Shrinking Globe in an Expanding Universe." The fair had a two-year run, from April 22-October 18, 1964, and from April 21-October 17, 1965. It featured 141 pavilions, sponsored by U.S. corporations, individual states, and countries around the world. The most prominent manifestation of the fair's theme was the Unisphere, a twelve-foot high stainless steel model of the earth, designed and fabricated by the United States Steel Corporation. The Unisphere was located at the center of the fairgrounds at the 


\section{Amy Spellacy}

Fountain of the Continents and was featured on tickets and promotional materials for the fair (Figure 6).

On the one hand, the physical and symbolic presence of the Unisphere at the fair directly challenged the construct of the hemisphere that had guided the logic and rhetoric of the Good Neighbor policy. While the idea of the hemisphere suggested that the world could be geographically divided into sections, and that these divisions had political and economic implications, the Unisphere provided a model of global unity. The shift away from the hemisphere and emphasis on the Unisphere at the fair echoed and built on the ideas of Air-Age Globalists, but also reflected U.S. economic and political agendas during the 1960s. At a time when the United States was focused on space exploration and concerned with Communism in Asia, the concept of the hemispheric neighborhood was no longer as relevant as it had once been. The fair reflected the massive shifts that had taken place in U.S. culture following World War II by promoting a global (rather than hemispheric) vision of world community, celebrating scientific and technological advancements, and showcasing the rise of U.S. corporate culture.

However, in spite of the move away from the hemisphere represented by the presence of the Unisphere, the "It's a Small World" exhibit at the fair illustrates how the rhetoric of the Good Neighbor policy provided the foundation for later models of international community that positioned the United States in the new role of global superpower. The "It's a Small World" exhibit, created by Disney for the United Nations Children's Fund (UNICEF) and sponsored by Pepsi, provides evidence of vestigial hemispheric rhetoric at the fair. Walt Disney personally asked Disney artist Mary Blair to come out of retirement to design the exhibit, which was inspired by Blair's work in The Three Caballeros, one of the defining cultural texts produced to promote the policy. Blair, who was particularly well known for her representations of children and her vibrant palettes, had been invited to accompany Disney and other Disney artists on the 1941 research trip to South America. On location in South America, Blair worked on conceptual paintings for the Disney features Saludos, Amigos and The Three Caballeros. ${ }^{65}$ Blair also traveled to Mexico on a survey trip in December 1942 and to Cuba to conduct preliminary research in $1943 .{ }^{66}$ In addition to shaping Disney's contributions to the Good Neighbor policy, Blair also painted two murals for Carmen Miranda's living room in 1945. ${ }^{67}$

Blair's sequence on the Mexican Christmas tradition of las posadas featured in The Three Caballeros later served as inspiration for "It's a Small World." Blair was responsible for the overall design and color styling of the exhibit, which promotes global harmony by taking visitors in boats on a virtual tour of the world, passing through Asia, Africa, the Pacific, and the Americas, ending in the United States. Along the way, dolls in native costumes represent children from around the world by performing local dances and playing local instruments while the song "It's a Small World" provides the unifying soundtrack. Laudan Nooshin draws attention to the similarities between the ride and a "colonial voyage of discovery" and suggests that the Euro-American, middle-class 


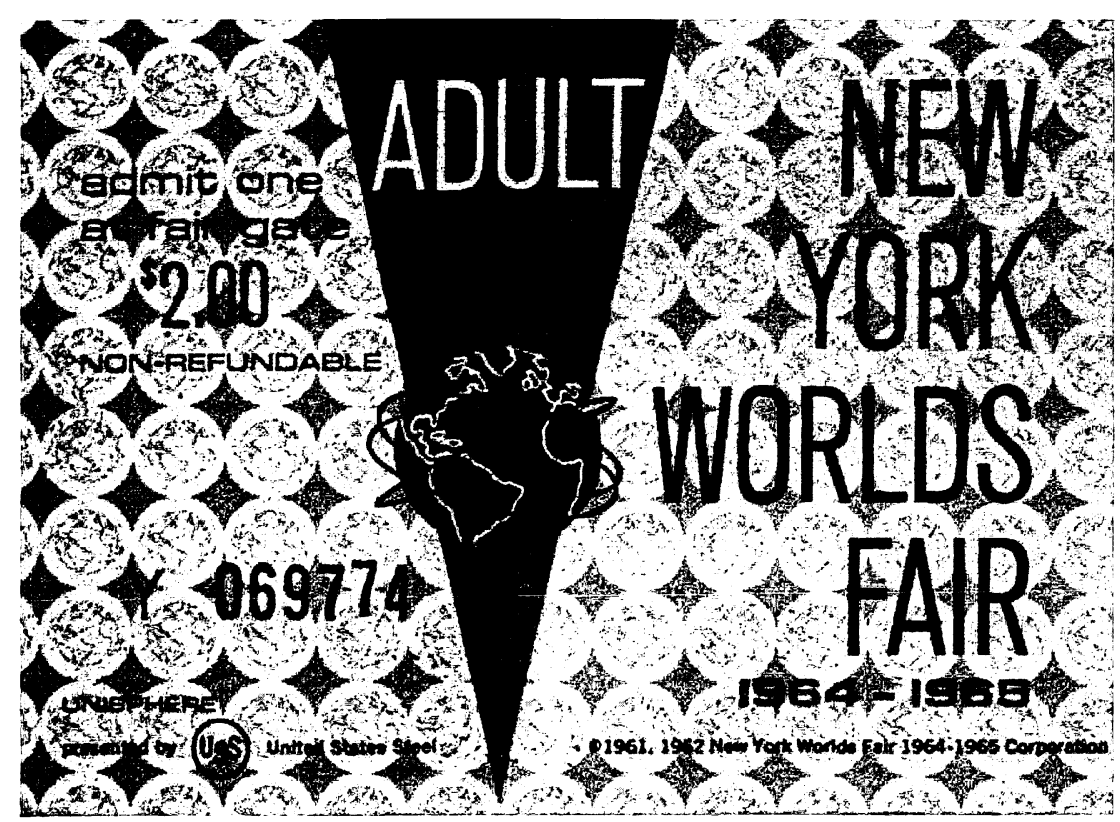

Figure 6: Ticket to the 1964-1965 World's Fair.

passengers have relative mobility and agency while the dolls remain fixed in position, on display in a manner that recalls the exhibition of native peoples at late nineteenth and early twentieth-century world fairs and exhibitions. ${ }^{68}$ The song, which follows predominantly Euro-American musical conventions, revolves around the idea that "we all sing the same song," homogenizing and appropriating the culture of the "others" featured in the ride. ${ }^{69}$

The predominant narrative of the ride is one of symbolic control over the rest of the world, by the U.S. Disney corporation and, by association, the United States. The ride suggests a global world community, in line with the theme of the fair as a whole, while also providing a colonial experience for people in the United States, placing them in a position of power in relation to people from less developed areas of the world. Like images of Roosevelt surveying his globe, which supported the strategic mapping techniques employed during the era of the Good Neighbor policy, the ride symbolically establishes U.S. global dominance through its creation of a vision of global harmony. In "It's a Small World," which was moved to Disneyland in 1966 and added to Walt Disney World in 1971, the United States serves as the puppeteer pulling the strings while the children of the world assure audiences of their cheerful participation in this vision.

Roosevelt's use of the metaphor of the good neighbor helped the United States to forge a new image of itself as a global power and make the transition to a position of dominance in the newly globalized world community following 
World War II. Neil Smith has suggested that the contemporary phenomenon of globalization needs to be understood as the result of an ongoing process that began during the early decades of the twentieth century, pointing to World War II as a watershed moment for the emergence of the United States as a global superpower. In his book on Roosevelt's geographer Isaiah Bowman, Smith draws a connection between World War II, the development of U.S. imperialism, and contemporary political and economic globalization:

There is no way to understand where the global shifts of the last twenty years came from or where they will lead without understanding how, throughout the twentieth century, U.S. corporate, political, and military power mapped an emerging empire.... First and foremost, though by no means exclusively, "globalization" was made in America and was built around U.S. interests and ideologies, but it was also established from the beginning of the twentieth century rather than simply at its end. ${ }^{70}$

As a key component in Roosevelt's domestic and international political rhetoric, the metaphor of the good neighbor helped Roosevelt to articulate and realize his vision of a new role for the United States in the global community.

And yet, although the metaphor of the good neighbor was no longer a central component of the rhetoric of U.S. foreign policy during the Cold War, U.S. preoccupation with the threat of Communism in the hemisphere suggests that the hemisphere was still an important category and that hemispheric proximity still mattered, as evidenced by the 1954 U.S.-led overthrow of Jacobo Arbenz in Guatemala. The global frenzy stirred up over the possibility of the spread of Communism made it especially urgent to deal with this issue in Latin America, where the specter of Communism created a sense of hemispheric crisis because of the geographic proximity to the United States. Arbenz, who had instituted agrarian reform and expropriated hundreds of thousands of acres of land belonging to United Fruit, was replaced by Colonel Carlos Castillo Armas, a military officer recruited by the CIA to lead the invasion force. Castillo Armas reversed the changes initiated by Arbenz and implemented policies more in line with U.S. economic and political goals.

And of course the United States was obsessed with the threat posed by Fidel Castro's government in Cuba, seen as especially menacing because of the proximity of Cuba, just 90 miles off the coast of Florida. In many ways, Roosevelt's 1941 view of the hemisphere as a protective barrier continued to shape U.S. policy regarding Cuba during the Cold War, most notably with the Bay of Pigs invasion in April 1961, and the Cuban Missile Crisis in October 1962, events driven by a desire to keep Communism at bay within the hemisphere and protect the U.S. mainland from the danger of a Soviet attack. In a statement issued on September 4, 1962, President Kennedy referred to the threat posed by 
Communism worldwide, but focused especially on the threat to the hemisphere: "The Cuban question must be considered as a part of the worldwide challenge posed by Communist threats to peace. It must be dealt with as a part of that larger issue as well as in the context of the special relationships which have long characterized the inter-American System.." In this same speech, Kennedy speaks of the need to protect the hemisphere as the primary motive for continuing to monitor the actions of Castro:

It continues to be the policy of the United States that the Castro
regime will not be allowed to export its aggressive purposes
by force or the threat of force. It will be prevented by whatever
means may be necessary from taking action against any part
of the Western Hemisphere. The United States, in conjunction
with other Hemisphere countries, will make sure that while
increased Cuban armaments will be a heavy burden to the
unhappy people of Cuba themselves, they will be nothing
more. ${ }^{72}$

The rhetorical weight given to the idea of hemispheric community suggests that it was still a significant category.

But even if the hemisphere still mattered, it was clear that the United States was no longer interested in being good neighbors. A 1961 political cartoon from the Philadelphia Inquirer symbolizes the extent to which the Good Neighbor policy was discarded and replaced by the principles that had previously guided U.S. policy with Latin America. In the cartoon, a Latin American man, wearing sandals and a large sombrero, is shown taking a nap while leaning against a tree marked with the words "Good Neighbor Policy." The faceless man has his hand extended, as if waiting for a hand-out, while a bag of money marked "U.\$. Aid" dangles from a branch above him. ${ }^{73}$ This openly hostile image reiterates the classic theme that Latin Americans are unable to manage their own affairs and implies that they are too lazy and unmotivated to help themselves.

Ironically, Castro himself was to later use the metaphor of the good neighbor to describe the relationship he wanted to see between the United States and Cuba. In 1975, when President Gerald Ford had taken steps toward normalizing relations with Cuba and ending the fifteen-year old trade embargo, U.S. journalist Barbara Walters asked Castro, "What would you like Americans to know about you and Cuba? And could you possibly say it in English, so they could understand?" 74 After initially protesting that his English is not very good, Castro answered, "Wish of understanding. Wish of friendship. I understand it is not easy. We belong to two different worlds. But I, we are ..." At this point, Castro, searching for the right word, leaned over to his interpreter and asked "¿Cómo se dice vecino?" and finished his sentence by declaring the United States and Cuba to be "neighbors." He continued, "And in one way or another, we ought to live in peace. The United States and Cuba." 


\section{Notes}

1. Sallie A. Marston, "The Social Construction of Scale," Progress in Human Geography 24, no. 2 (2000): 233 .

2. In this essay, I use the term "virtual" to describe the experiences of people in the United States who vicariously learned about Latin America through the words and images of others in books, films, and radio broadcasts. I do not mean to evoke contemporary uses of the term to describe experiences mediated by computer technology.

3. Historians typically mark the beginning of the Good Neighbor policy with either Hoover's 1928 goodwill tour of Latin America or with Roosevelt's inaugural address on March 4, 1933. Roosevelt dedicated the majority of his 1933 address to outlining a program of domestic economic recovery and encouraging Americans to brace themselves for the hard work that lay ahead in battling the depression. Although the speech does not specifically mention Latin America, the one short paragraph on foreign policy is usually cited as FDR's declaration of the Good Neighbor policy: "In the field of world policy I would dedicate this Nation to the policy of the good neighbor-the neighbor who resolutely respects himself and, because he does so, respects the rights of others - the neighbor who respects his obligations and respects the sanctity of his agreements in and with a world of neighbors." See Edgar B. Nixon, ed., Franklin D. Roosevelt and Foreign Affairs (3 vols.; Cambridge: Belknap Press of Harvard University Press, 1969), I: 20.

4. Neil Smith, "Homeless/Global: Scaling Places," in Mapping the Futures: Local Cultures, Global Change, ed. John Bird, et al. (London: Routledge, 1993), 99.

5. Henri Lefebvre, The Production of Space, trans. Donald Nicholson-Smith (Malden, MA: Blackwell Publishing, 1991).

6. Marston, "The Social Construction of Scale," 220.

7. Smith, "Homeless/Global: Scaling Places," 101.

8. Ibid., 90 .

9. Neil Brenner, "State Territorial Restructuring and the Production of Spatial Scale: Urban and Regional Planning in the Federal Republic of Germany, 1960-1990," Political Geography 16 (May 1997): 280.

10. Smith, "Homeless/Global: Scaling Places," 105.

11. James C. Scott, Seeing Like a State: How Certain Schemes to Improve the Human Condition Have Failed (New Haven: Yale University Press, 1998), 82.

12. Franklin D. Roosevelt, "On the Declaration of War with Japan," Radio Address, December 9, 1941. Franklin D. Roosevelt Library Digital Archives, www.fdrlibrary.marist.edu (accessed May 1, 2006).

13. See Scott, Seeing Like a State, 82.

14. J.B. Harley, "Maps, Knowledge, and Power," in The New Nature of Maps: Essays in the History of Cartography, ed. Paul Laxton (Baltimore: Johns Hopkins University Press, 2001), 54.

15. Ibid., 53.

16. Alexander Cowie, "The Arts and the War," The Saturday Review of Literature, June 28, $1941,3$.

17. During his first two terms in office Roosevelt used the "good neighbor" to describe and promote his domestic as well as his international policies. The metaphor of the good neighbor served as a bridge between Roosevelt's domestic and international policies and programs, signifying ideals of service and community in both realms. Most significantly, the metaphor of the good neighbor was used by the Good Neighbor League to defend and sell Roosevelt's New Deal policies to U.S. citizens during the 1936 re-election campaign. The League, which was formed by a group of influential supporters to assist with Roosevelt's re-election, launched a comprehensive publicity campaign that emphasized the social and economic progress already achieved through the New Deal and outlined a program for the future that stressed interdependence and mutual understanding across economic, racial, and religious divisions in the United States.

18. Alan K. Henrikson, "The Map as an 'Idea': The Role of Cartographic Imagery During the Second World War," The American Cartographer 2, no. 1 (1975): 20.

19. Ibid., 21.

20. Franklin D. Roosevelt, Radio Address, February 23, 1942, "Fireside Chats," Franklin D. Roosevelt Library Digital Archives, www.fdrlibrary.marist.edu (accessed May 1, 2006).

21. Ibid.

22. Ibid.

23. Museum Display, July 21, 2004; Franklin D. Roosevelt Library, Hyde Park, New York.

24. Ibid.

25. Isaiah Bowman, "Franklin Delano Roosevelt 1882-1945," The Geographical Review 35 (July 1945): 349.

26. Harley, "Maps, Knowledge, and Power," 71-73. 
27. Henrikson, "The Map as an 'Idea," 24.

28. Ibid.

29. Ibid., 23.

30. Ibid., 26.

31. Richard Edes Harrison, "The War of the Maps: A Famous Cartographer Surveys the Field," The Saturday Review of Literature, August 7, 1943, 25.

32. Henrikson, "The Map as an 'Idea," 28.

33. Arthur P. Whitaker, The Western Hemisphere Idea: Its Rise and Decline (Ithaca: Cornell University Press, 1954), 7.

34. Gretchen Murphy, Hemispheric Imaginings: The Monroe Doctrine and Narratives of U.S. Empire (Durham: Duke University Press, 2005). By suggesting that the rhetoric of the Good Neighbor policy also relied on and participated in shaping the geographical construct of the Western Hemisphere, I am making an argument that runs parallel to Murphy's argument. However, I argue that the relationship between the idea of the Western Hemisphere and the Good Neighbor policy is especially striking given that the architects of the policy clung to the concept of the hemisphere at a time when it was challenged by geographers. While Murphy points to the simultaneous decline of the Monroe Doctrine and the idea of the hemisphere during the 1930s, I suggest that the hemisphere was kept alive by the Good Neighbor policy in order to provide a structure and logic for U.S.-Latin American policy through the 1940s, in spite of the scientific push to abandon the concept.

35. Henrikson, "The Map as an 'Idea," 30.

36. Lawrence Martin, "The Geography of the Monroe Doctrine and the Limits of the Western Hemisphere," The Geographical Review 30 (July 1940): 526.

37. Henrikson, "The Map as an 'Idea," 28.

38. Eugene Staley, "The Myth of the Continents," Foreign Affairs 19 (April 1941): 485. Staley establishes his position in contrast to books that supported hemispheric isolationism, including Charles A. Beard, A Foreign Policy for America (New York: A.A. Knopf, 1940), Jerome Frank, Save America First: How to Make Our Democracy Work (New York: Harper \& Brothers, 1938), and Stuart Chase, The New Western Front (New York: Harcourt, Brace and Company, 1939).

39. Staley, "The Myth of the Continents," 485.

40. Ibid.

41. Staley argues that "In short, land connections, which would appear to establish easy contact between peoples on the same continent, may be barriers as well as connections, while bodies of water, appearing superficially on the map as barriers, may actually be most important connecting links" (486-87).

42. Ibid., 494.

43. Francis Pickens Miller, "The Atlantic Area," Foreign Affairs 19 (July 1941): 727-28.

44. Ibid., 728.

45. "The Americas Brought Nearer," The Literary Digest, June 1, 1935, 47.

46. Nixon, ed., Franklin D. Roosevelt and Foreign Affairs, III: 423.

47. George T. Renner, "What the War Has Taught Us About Geography," Journal of Geography 43 (December 1944): 326.

48. In The Good Neighbor: How the United States Wrote the History of Central America and the Caribbean (New York: Pantheon Books, 1988), George Black also suggests that these improvements in transportation technology encouraged North Americans to travel to Latin America: "the United States' first strides in international airline and road travel opened up Central America to large-scale tourism, while Good-Neighbor sentiment encouraged travelers to believe that the local inhabitants were really their brothers and sisters (or at least their country cousins) under the skin" (62).

49. Black, The Good Neighbor, 65.

50. Ibid.

51. Wesley Phillips Newton, "Pan American Airways," The Encyclopedia of American Business History and Biography (New York: Facts on File, 1988), 343.

52. Advertisement for Moore-McCormack Lines, National Geographic, June 1948.

53. Constance Matilda Jordan Henley, Grandmother Drives South (New York: G.P. Putnams Sons, 1943); Milton Reynolds, Hasta La Vista (I'll Be Seeing You) (New York: Greenburg, 1944); Herbert Cerwin, These Are the Mexicans (New York: Reynal \& Hitchcock, 1947).

54. Carleton Beals, Pan America: A Program for the Western Hemisphere (Boston: Houghton Mifflin, 1940).

55. John L. Strohm, I Lived with Latin Americans (Danville, Ill.: Interstate, 1943).

56. The Three Caballeros, 1945, Directed by Norman Ferguson, Walt Disney Home Video, 2000, DVD.

57. Julianne Burton-Carvajal, “'Surprise Package': Looking Southward with Disney," in Disney Discourse: Producing the Magic Kingdom, ed. Eric Smoodin (New York: Routledge, 1994), 133. 


\section{Amy Spellacy}

58. Walt Disney's close working relationship with the Office of the Coordinator of InterAmerican Affairs is well documented and has been examined by contemporary scholars. For more information on Disney's support of the war effort and of the Good Neighbor policy, see Smoodin's edited collection, Disney Discourse: Producing the Magic Kingdom. See especially Smoodin's "Introduction: How to Read Walt Disney," Julianne Burton-Carvajal's " "Surprise Package': Looking Southward with Disney," José Piedra's "Pato Donald's Gender Ducking," and Lisa Cartwright and Brian Goldfarb's "Cultural Contagion: On Disney's Health Education Films for Latin America." Burton-Carvajal reads The Three Caballeros as an allegory of firstworld colonialism and suggests that the film employs "Good-Neighborliness as foil for empirebuilding as usual" (147). José Piedra considers sexual innuendoes and gender in the same film. For a general overview of Disney's involvement in Latin America, see "South of the Border with Disney," Chapter 4 of Richard Shale's Donald Duck Joins Up: The Walt Disney Studio During World War II (Ann Arbor: UMI Research Press, 1982).

59. Burton-Carvajal also comments on the ways that Donald is transported into the spectacular world of the other during the film. She suggests that the core segments of the film focus on a "dual configuration" of "demonstration and transportation" and that in the sections focused on transportation, Donald's "passive contemplation gives way to direct participation" (137).

60. "Theatrical Trailer," The Three Caballeros, 1945.

61. Julianne Burton-Carvajal and José Piedra also discuss Donald's overactive libido.

62. Black, The Good Neighbor, 89.

63. See Richard M. Freeland, The Truman Doctrine and the Origins of McCarthyism: Foreign Policy, Domestic Politics, and Internal Security, 1946-1948 (New York: Alfred A. Knopf, 1972).

64. Whitaker, The Western Hemisphere Idea, 154-55.

65. John Canemaker, The Art and Flair of Mary Blair: An Appreciation (New York: Disney Editions, 2003), ix.

66. Ibid., 20.

67. Ibid., 22.

68. Laudan Nooshin, "Circumnavigation with a Difference? Music, Representation and the Disney Experience," Ethnomusicology Forum 13 (November 2004): 240. Nooshin also discusses how the ride masks the realities of exploitation and domination of global corporations, such as Disney.

69. Nooshin, "Circumnavigation with a Difference," 243.

70. Neil Smith, American Empire: Roosevelt's Geographer and the Prelude to Globalization (Berkeley: University of California Press, 2003), 4.

71. U.S. Department of State, Bulletin XLVII (September 24, 1962). Read to news correspondents on September 4, by Pierre Salinger, White House Press Secretary.

72. Ibid. 67.

73. John J. Johnson, Latin America in Caricature (Austin: University of Texas Press, 1980),

74. Archival film footage used in documentary Fidel Castro, written, produced, and directed by Adriana Bosch, PBS American Experience, 2005.

75. Ibid. 